\title{
CHANGES OF PHYSICAL-CHEMICAL PROPERTIES OF BEEF DURING 14 DAYS OF CHILLING
}

\author{
N. Stanišićc ${ }^{1}$ M. Petričević ${ }^{1}$, D. Živković ${ }^{2}$, M. M. Petrović ${ }^{1}$, D. Ostojić- \\ Andrić $^{1}$, S. Aleksić ${ }^{1}$, S. Stajić ${ }^{2}$ \\ ${ }^{1}$ Institute for Animal Husbandry, Autoput 16, 11080, Belgrade-Zemun, Republic of Serbia \\ ${ }^{2}$ Faculty of Agriculture, Nemanjina 6, 11080, Belgrade-Zemun, Republic of Serbia \\ Corresponding author: nikola0135@yahoo.com \\ Original scientific paper
}

Abstract: The objective of the work was to evaluate the effect of conditioning time (during 14 days of ageing at $+4^{\circ} \mathrm{C}$ ) on physicochemical properties of two cattle skeletal muscles. Investigations were conducted on the $m$. longissimus dorsi $(\mathrm{n}=9)$ and m. gluteus medius $(\mathrm{n}=9)$ of Domestic Spotted breed. Muscle analyses were carried out $1^{\text {st }}, 7^{\text {th }}$ and $14^{\text {th }}$ day post mortem, during storage at $+4^{\circ} \mathrm{C}$. Colour (CIE L*a*b* values, Hue and Chroma), cooking loss, shear force, water-holding capacity (WHC), $\mathrm{pH}$ value and sensory characteristics were determined in all meat samples. M. longissimus dorsi samples aged for 14 days were characterized by higher degree of lightness $\left(\mathrm{L}^{*}\right)$ and chroma $\left(\mathrm{C}^{*}\right)$ values, more of red colour (higher $\mathrm{a}^{*}$ ) and of yellow (higher $\mathrm{b}^{*}$ ), while $m$. gluteus medius colour changes during storage was not found to be significant. Over the 14 day conditioning period, tenderness (expressed as shear force) of the evaluated muscles improved significantly $(\mathrm{p}<0.05)$, it ranged from $11.50 \mathrm{~kg} / \mathrm{cm}^{2}\left(1^{\text {st }}\right.$ day) to 5.00 $\mathrm{kg} / \mathrm{cm}^{2}\left(14^{\text {th }}\right.$ day) for $m$. longissimus dorsi and from $9.81 \mathrm{~kg} / \mathrm{cm}^{2}\left(1^{\text {st }}\right.$ day) to 5.10 $\mathrm{kg} / \mathrm{cm}^{2}\left(14^{\text {th }}\right.$ day) for $m$. gluteus medius muscle. Cooking loss and WHC increased significantly over storage time $(\mathrm{p}<0.05)$ in both meat samples, while changes in $\mathrm{pH}$ values were insignificant. Sensory analyses revealed deterioration in flavour (smell and taste) and improvement in tenderness of roasted meat samples during storage. scores

Key words: cold storage, meat colour, technological quality, sensory

\section{Introduction}

Factors affecting the quality of meat can be divided into ante mortem (genetic background, housing, starving before slaughtering, etc.) and post mortem (slaughtering procedure, storage and cooling of meat) (Aleksić et al., 2011). Low temperature storage is one of the primary preservation methods to maintain meat freshness, because the rates of microbiological, chemical and biochemical changes 
are reduced at decreased temperatures. Since post-mortem refrigerated storage of meat, often termed maturation or ageing, permits desirable degradative structural changes in myofibrillar, cytoskeletal and connective tissue proteins which enhances its palatability (Ouali, 1990; Takahashi, 1996), beef is often not sold until at least 14 days post-mortem (Dunne et al., 2010). Furthermore, it is well understood that these factors differ among muscles within a carcass (McKenna et al., 2005; Seyfert et al., 2006).

In a retail environment, colour is affected at all steps of the production chain, including chilling variables and ageing time, and it is a critical sensory characteristic of beef as it is experienced by consumers before tenderness or flavour and tends to be used as an indicator of perceived quality and freshness (Carpenter et al., 2001). The colour of meat is primarily dependant on the concentration and chemical state of the pigment myoglobin, which is responsible for moving oxygen through the muscle.

Beef carcasses are held in refrigerated storage for varying periods to improve tenderness, the most important meat quality trait (Ouali, 1990; Miller et al., 2001). The rate of ageing varies by species and by cut. For example, beef forequarter and fillet cuts do not need the same maturation as hindquarter cuts, which can be anything between seven and 21 days (Houbak et al., 2008). In this sense, inadequate tenderness is the most important cause of consumer dissatisfaction and any improvement in tenderness would increase the value of the final product (Vieira et al., 2006).

The objective of the present study was to evaluate the effect of storage time at $+4^{\circ} \mathrm{C}$ on physicochemical properties of two beef skeletal muscles of Domestic spotted breed, which is the most common cattle breed in Serbia.

\section{Materials and Methods}

Research was carried out on 9 samples of $m$. longissimus dorsi muscle and 9 samples of $m$. gluteus medius of young cattle of Domestic spotted genotype, average mass prior slaughter of $700 \mathrm{~kg}$. Breeding of cattle, slaughtering and laboratory analyses of meat were carried out in the Institute for animal husbandry (Belgrade, Serbia). During the fattening period the rearing system was free, and food consisted of concentrated feeds, hay and corn grain silage. One day before slaughtering cattle were deprived of food, but had free access to water. After slaughtering and primary processing, carcasses were chilled at $+4^{\circ} \mathrm{C}$ for 24 hours.

After chilling, samples of meat were taken of the loin section of the back muscle ( $m$. longissimus dorsi) between $12^{\text {th }}$ and $13^{\text {th }}$ rib and from the leg section ( $m$. gluteus medius). Every muscle sample was divided into three equal parts, one part was immediately used for analysis $\left(1^{\text {st }}\right.$ day). The remaining two parts, packed 
in aluminum foil and stored at temperature $+4^{\circ} \mathrm{C}$, were analyzed $7^{\text {th }}$ and $14^{\text {th }}$ days after salughtering.

Analyses of muscle samples were done $1^{\text {st }}, 7^{\text {th }}$ and $14^{\text {th }}$ days after slaughtering. Water holding capacity (WHC) was done according to method by Grau et al. (1953). pH value of meat was measured using pH-meter Hanna, HI 83141 (Hanna Instruments, USA). Cooking loss was determined in the following way: sample of size of $3 \times 4 \times 1.5 \mathrm{~cm}$ is weighed and put into glass with boiling water and cooked for 10 minutes; difference in mass of sample before and after cooking represents loss of mass during heat treatment and it is expressed in percentages. Samples used for determination of cooking loss were also used for determination of meat shear force $\left(\mathrm{kg} / \mathrm{cm}^{2}\right)$ : muscles have been cut to parts of size of $1 \mathrm{x} 1 \mathrm{~cm}$ in the direction of muscle fibre extension; meat tenderness, expressed by shear force, was measured on Warner-Bratzler apparatus at a crosshead speed of $150 \mathrm{~mm} / \mathrm{min}$; higher values read out on the apparatus marked higher values of shear force, i.e. firmer meat.

The colour of fresh cut meat surface following $30 \mathrm{~min}$ blooming time (samples were stored in contact with air at $4^{\circ} \mathrm{C}$ ) was measured using Minolta CR410 portable chromameter (illumination D65, geometry 0 projection angle and 50 $\mathrm{mm}$ measure area). Values were given in the colour space CIE (CIE, 1976), where $\mathrm{L}^{*}$ - metrical lightness; $\mathrm{a}^{*}$ - redness; $\mathrm{b}^{*}$ - yellowness. Three readings were made on non-overlapping areas of the muscles and the average value was used for data analysis. Hue angle $\left(\mathrm{H}^{\mathrm{o}}-\right.$ true redness) was calculated as [arctangent $\left(\mathrm{b}^{*} / \mathrm{a}^{*}\right) \times$ 180/3.142] and chroma ( $\mathrm{C}^{*}$ - color intensity; also known as saturation index) was

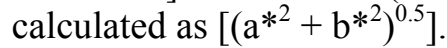

Sensory analysis was done by seven semi-trained evaluators on samples of meat size of $5 \times 3 \times 2 \mathrm{~cm}$ after roasting at a temperature of $180-190^{\circ} \mathrm{C} / 10 \mathrm{~min}$. In sensory evaluation, the 5 points system was used: from 1-extremely unacceptable to 5-extremely acceptable. The following attributes of roasted meat were scored: smell, taste and tenderness.

In order to determine the effect of storage time at $+4^{\circ} \mathrm{C}$ on meat characteristics, a single-factor analysis of variance was performed using Statistica 7 software (StatSoft, USA). If the effect of storage was found significant, Tukey's test was used to evaluate the significance of difference at $p<0.05$.

\section{Results and Discussion}

Although meat colour is a poor guide to eating quality, most consumers make purchase decisions based on display colour. Consumers discriminate against meat that is not red and bright, considering it is old or of poor quality (Young et al., 1999). The length of time meat is kept in chilled storage has an effect on the rate of colour change (Table 1). Feldhusen et al. (1995) showed that there were clear 
colour changes in beef $m$. longissimus dorsi during cold storage for up to 5 days at $+5^{\circ} \mathrm{C}$. The author stated that the degree of lightness $\left(\mathrm{L}^{*}\right)$, percentage of red colour $\left(a^{*}\right)$ and percentage of yellow colour $\left(b^{*}\right)$ all increased during storage, which was confirmed by results obtained in this trial.

Hue angle is the development of color from red to yellow and larger angles indicate a less red product. Chroma is used to indicate the saturation of color, sometimes termed vividness (Tapp et al., 2011). $\mathrm{H}^{\mathrm{o}}$ and $\mathrm{C}^{*}$ values increased with the storage duration, however statistically significant difference was determined only in chroma values for $m$. longissimus dorsi (Table 1). Oliete et al. (2006) found that lengthening of the vacuum storage time of $m$. longissimus thoracis muscle $\left(1^{\text {st }}\right.$, $7^{\text {th }}$ and $14^{\text {th }}$ day) resulted in a rise of the $a^{*}$ and $b^{*}$ parameters, i.e. meat became more red and yellow, with a more pink hue (higher $\mathrm{H}^{\circ}$ ), while the colour saturation was more intensive (higher $\mathrm{C}^{*}$ ).

Table 1. Effect of storage time on CIE $L * a * b *$, hue angle and chroma values (mean \pm standard deviation)

\begin{tabular}{|c|c|c|c|c|c|}
\hline Sample / day & $\mathrm{L}^{*}$ & $\mathrm{a}^{*}$ & $\mathrm{~b}^{*}$ & $\mathrm{H}^{\mathrm{o}}$ & $\mathrm{C}^{*}$ \\
\hline M. longissimus dorsi & $36.36^{\mathrm{b}} \pm 1.06$ & $19.80^{\mathrm{c}} \pm 0.87$ & $6.69^{\mathrm{b}} \pm 1.30$ & $18.54^{\mathrm{b}} \pm 2.90$ & $20.92^{\mathrm{b}} \pm 1.18$ \\
\hline $1^{\text {st }}$ & $37.58^{\mathrm{ab}} \pm 1.08$ & $20.46^{\mathrm{b}} \pm 0.54$ & $7.46^{\mathrm{ab}} \pm 0.58$ & $20.01^{\mathrm{ab}} \pm 1.04$ & $21.78^{\mathrm{ab}} \pm 0.69$ \\
\hline $7^{\text {th }}$ & $38.51^{\mathrm{a}} \pm 1.65$ & $21.20^{\mathrm{a}} \pm 0.85$ & $7.99^{\mathrm{a}} \pm 0.97$ & $20.57^{\mathrm{a}} \pm 1.62$ & $22.67^{\mathrm{a}} \pm 1.12$ \\
\hline $14^{\text {th }}$ & $37.58 \pm 0.86$ & $20.15 \pm 1.17$ & $6.61 \pm 1.00$ & $18.09 \pm 1.57$ & $21.21 \pm 1.42$ \\
\hline M. gluteus medius \\
\hline $1^{\text {st }}$ & $37.73 \pm 0.99$ & $20.24 \pm 1.09$ & $6.77 \pm 1.04$ & $18.41 \pm 1.76$ & $21.35 \pm 1.35$ \\
\hline $7^{\text {th }}$ & $37.83 \pm 0.34$ & $20.56 \pm 0.35$ & $7.17 \pm 0.26$ & $19.23 \pm 0.54$ & $21.77 \pm 0.38$ \\
\hline $14^{\text {th }}$ & 5
\end{tabular}

$\mathrm{a}, \mathrm{b}, \mathrm{c}$ : values in the same column with different superscript are significantly different $(\mathrm{p}<0.05)$

The cooking loss from the samples was monitored through the storage period (Table 2). Cooking led to a systematic and significant loss of matter and the cooking yields differed depending on the muscle and cooking process (Gerber et al., 2009). In this trial, cooking loss increased with storage duration in both analyzed muscles, however statistically significant increase in regard to this parameter was established only in $m$. gluteus medius muscle, stored for 14 days $(\mathrm{p}<0.05)$.

According to Ouali (1990) meat tenderness is affected by the origin and age of animals, their sex, breed, environmental conditions associated with the preslaughter stress, the slaughter itself as well as the time of meat ageing. Most studies have shown that the major improvement in tenderness occurs in less than 14 days of aging (James and James, 2002). An objective measure of tenderness is the force required to shear a piece of meat with low shear values being desirable. Decrease of the value of shear force with the increase of storage duration (Table 2), i.e. increase of tenderness, which was established in this study, is a typical phenomenon reported by other authors (Huff-Lonergan et a., 1996, Florek et al., 2007; Iwanowska et al., 2010). Boleman et al. (1997) suggested the following 
categories for beef steaks on the grounds of the Warner-Bratzler force: tender from 2.27 up to $3.58 \mathrm{~kg}$, moderate $4.08-5.40 \mathrm{~kg}$ and tough $5.90-7.21 \mathrm{~kg}$. According to this, the ultimate $m$. longissimus dorsi and $m$. gluteus medius tenderness (after $14^{\text {th }}$ days of ageing) shown in the present studies, implies that it belongs to the tough category.

Table 2 shows the changes in water holding capacity (WHC) in the meat samples during storage. WHC values decreased significantly over storage time $(\mathrm{p}<0.05)$ in both meat samples. This is in agreement with research of Jouki and Khazaei (2011), who investigated the effects of low temperature storage time on some characteristics of camel meat.

Table 2. Effect of storage time on technological quality of meat (mean \pm standard deviation)

\begin{tabular}{|c|c|c|c|c|}
\hline Sample/day & Cooking loss & Sheare force & WHC & $\mathrm{pH}$ \\
\hline M. longissimus dorsi & \multicolumn{5}{|l|}{} \\
\hline $1^{\text {st }}$ & $42.38 \pm 1.48$ & $11.50 \mathrm{a} \pm 1.01$ & $11.78^{\mathrm{b}} \pm 0.78$ & $5.49 \pm 0.05$ \\
\hline $7^{\text {th }}$ & $43.41 \pm 1.42$ & $7.57 \mathrm{~b} \pm 0.59$ & $12.52^{\mathrm{ab}} \pm 0.30$ & $5.47 \pm 0.08$ \\
\hline $14^{\text {th }}$ & $43.34 \pm 1.74$ & $5.00 \mathrm{c} \pm 0.40$ & $13.80^{\mathrm{a}} \pm 0.35$ & $5.65 \pm 0.14$ \\
\hline M. gluteus medius \\
\hline $1^{\text {st }}$ & $43.36^{\mathrm{b}} \pm 0.43$ & $9.81^{\mathrm{a}} \pm 1.25$ & $12.18 \pm 0.95$ & $5.44 \pm 0.04$ \\
\hline $7^{\text {th }}$ & $44.43^{\mathrm{ab}} \pm 0.19$ & $7.56^{\mathrm{b}} \pm 0.71$ & $14.15 \pm 1.11$ & $5.39 \pm 0.02$ \\
\hline $14^{\text {th }}$ & $45.82^{\mathrm{a}} \pm 0.95$ & $5.10^{\mathrm{c}} \pm 0.41$ & $13.95 \pm 1.03$ & $5.51 \pm 0.02$ \\
\hline
\end{tabular}

$\mathrm{a}, \mathrm{b}, \mathrm{c}$ : values in the same column with different superscript are significantly different $(\mathrm{p}<0.05)$

The $\mathrm{pH}$ variations for meat samples according to the storage time have been shown in Table 2 . There was a slight and constant growth in $\mathrm{pH}$ value in both muscles till the $14^{\text {th }}$ day of storage, but this growth was not found to be significant. This rise of the $\mathrm{pH}$ value during storage (ageing) arises from the progressing alkalization caused by the release of basic products of protein breakdown throughout the post-slaughter endogenous changes (Florek et al., 2007).

The roasted meat samples were evaluated for sensory attributes, such as smell, taste and tenderness by semi-trained panelists (Table 3). In both analyzed muscles, duration of storage had impact on significant deterioration of the smell and aroma of roasted meat, probably due to increase activity of microorganisms and spoilage. On the other hand, scores for tenderness of roasted meat were significantly higher for samples stored for 14 days (Table 3), which is in accordance with previously presented values for shear force (Table 2). Consumer sensory assessments of non-aged beef are variable, ranging from "moderately tough" to "moderately tender" whilst beef conditioned for 9 days at $1^{\circ} \mathrm{C}$ receives largely favourable reactions, being scored "moderately" to "very" tender (James and James, 2002). 
Table 3. Effect of storage time on sensory scores of roasted meat (mean \pm standard deviation)

\begin{tabular}{|c|c|c|c|}
\hline Sample/day & Smell & Taste & Tenderness \\
\hline M. longissimus dorsi & $4.9^{\mathrm{a}} \pm 0.20$ & $4.5^{\mathrm{a}} \pm 0.10$ & $3.8^{\mathrm{c}} \pm 0.16$ \\
\hline $1^{\text {st }}$ & $4.8^{\mathrm{ab}} \pm 0.17$ & $4.7^{\mathrm{a}} \pm 0.12$ & $4.5^{\mathrm{b}} \pm 0.09$ \\
\hline $7^{\text {th }}$ & $3.8^{\mathrm{b}} \pm 0.19$ & $3.9^{\mathrm{b}} \pm 0.12$ & $5.0^{\mathrm{a}} \pm 0.11$ \\
\hline $14^{\text {th }}$ & $4.5^{\mathrm{a}} \pm 0.16$ & $4.0^{\mathrm{c}} \pm 0.19$ \\
\hline M. gluteus medius & $4.0^{\mathrm{ab}} \pm 0.16$ & $4.2^{\mathrm{ab}} \pm 0.14$ & $4.4^{\mathrm{b}} \pm 0.12$ \\
\hline $1^{\text {st }}$ & $4.3^{\mathrm{a}} \pm 0.21$ & $3.9^{\mathrm{b}} \pm 0.21$ & $4.9^{\mathrm{a}} \pm 0.10$ \\
\hline $7^{\text {th }}$ & $3.5^{\mathrm{b}} \pm 0.20$ &
\end{tabular}

$\mathrm{a}, \mathrm{b}, \mathrm{c}$ : values in the same column with different superscript are significantly different $(\mathrm{p}<0.05)$

\section{Conclusion}

In this study the changes during cold storage of parameters that affected meat quality of Domestic spotted breed have been observed. In general, the significant differences were found for colour attributes, cooking loss, share force, WHC and sensory scores. 14 day storage at the temperature $+4^{\circ} \mathrm{C}$ induces significant changes in colour of $m$. longissimus dorsi, however, this change was not established in $m$. gluteus medius. Tenderness of meat samples showed a substantial significant improvement, which for the $m$. gluteus medius was determined after 7 days and for $m$. longissimus dorsi, after 14 days of the conditioning period. Storage had effect on decrease of the water holding capacity and increase of cooking loss, i.e. reduction of the technological quality of meat. Significant changes occurred in sensory analysis of roasted meat where scores for smell and aroma decreased significantly, whereas for tenderness they increased with the duration of storage.

\section{Acknowledgements}

Research was financed by the Ministry of Education and Science, Republic of Serbia, project TR-31053.

\section{Promene u fizičko-hemijskim karakteristikama junećeg mesa tokom 14 dana hlađenja}

N. Stanišić, M. Petričević, D. Živković, M. M. Petrović, D. Ostojić-Andrić, S. Aleksić, S. Stajić

\section{Rezime}

Cilj ovog istraživanja je bio da se ispita efekat vremena kondicioniranja (tokom 14 dana zrenja na $+4^{\circ} \mathrm{C}$ ) na fizičko-hemijske karakteristike dva mišića 
junadi. Ispitivanja su obavljena na m.longissimus dorsi $(\mathrm{n}=9)$ i $m$. gluteus medius $(n=9)$ junadi domaće šarene rase. Analize mišića su rađene prvog, sedmog i četrnaestog dana od dana klanja, tokom skladištenja na $+4^{\circ} \mathrm{C}$. U svim uzorcima mišića je utvrđena boja (CIE L*a*b*, $\mathrm{H}^{0}$ i $\mathrm{C}^{*}$ vrednosti), kalo kuvanja, sila sečenja, sposobnost vezivanja vode, $\mathrm{pH}$ vrednost i senzorna analiza. Nakon skladištenja od 14 dana uzorci $m$. longissimus dorsi su imali viši stepen svetloće (L*) i hroma vrednosti $\left(C^{*}\right)$, veći udeo crvene (više a*) i žute boje (više $b^{*}$ ), dok u uzorcima $m$. gluteus medius nije utvrđena statistički značajna promena u parametrima boje. Tokom 14 dana skladištenja, mekoća mesa (izražena kao sila sečenja) se značajno poboljšala $(\mathrm{p}<0.05)$, od $11.50 \mathrm{~kg} / \mathrm{cm}^{2}$ (prvog dana) do 5.00 $\mathrm{kg} / \mathrm{cm}^{2}$ (četrnaestog dana) za $m$. longissimus dorsi i od $9.81 \mathrm{~kg} / \mathrm{cm}^{2}$ (prvog dana) do $5.10 \mathrm{~kg} / \mathrm{cm}^{2}$ (četrnaestog dana) za m. gluteus medius. Kalo kuvanja i sposobnost vezivanja vode su se značajno povećali $(\mathrm{p}<0.05)$ kod oba mišića, dok se $\mathrm{pH}$ vrednost nije značajno menjala tokom skladištenja. Tokom senzorne analize pečenog mesa utvrđeno je pogoršanje arome (ukusa i mirisa) i poboljšanje mekoće sa vremenom skladištenja.

\section{References}

ALEKSIĆ S., PETROVIĆ M.M., PANTELIĆ V., NOVAKOVIĆ Ž., OSTOJIĆANDRIĆ D., STANIŠIĆ N., NIKŠIĆ D. (2011): Chemical, technological and sensory properties of meat from different cattle genotypes. 3rd International Congress "New Perspectives and Challenges of Sustainable Livestock Production", 5-7th october Belgrade, Biotechnology in Animal Husbandry, 27, 913-918.

BOLEMAN S.J., BOLEMAN S.L., MILLER R.K., TAYLOR J.F., CROSS H.R., WHEELER T.L., KOOHMARAIE M., SHACKELFORD S.D., MILLER M.F., WEST R.L., JOHNSON D.D., SAVELL J.W. (1997): Consumer evaluation of beef of known categories of tenderness. Journal of Animal Science, 75, 1521-1524.

CARPENTER C.E., CORNFORTH D.P., WHITTIER D. (2001): Consumer preferences for beef color and packaging did not affect eating satisfaction. Meat Science, 57, 359-363.

CIE (1976), Commission Internationale de 1'Eclairage, Colorimetry, $2^{\text {nd }}$ ed., Vienna.

DUNNE P.G., MONAHAN F.J., MOLONEY A.P. (2010): A note on the effect of post-mortem maturation on colour of bovine Longissimus dorsi muscle. Irish Journal of Agricultural and Food Research, 49, 153-158.

FELDHUSEN F., WARNATZ A., ERDMANN R., WENZEL S. (1995): Influence of storage time on parameters of colour stability of beef. Meat Science, 40, 235243. 
FLOREK M., LITWIŃCZUK A., SKAŁECKI P., RYSZKOWSKA-SIWKO M. (2007): Changes of physicochemical properties of bullocks and heifers meat during 14 days of ageing under vacuum. Pol. J. Food Nutr. Sci., 57, 281-288.

GERBER N., SCHEEDER M.R.L., WENK C. (2009): The influence of cooking and fat trimming on the actual nutrient intake from meat. Meat Science, 81, 148-154.

GRAU R., HAMM R., BAUMANN A. (1953). Über das Wasserbindungsvermögen des toten Säugetiermuskels. I. Mitteilung. Der Einfluß des $\mathrm{pH}$ Wertes auf die Wasserbindung von zerkleinertem Rindermuskel. Biochem. Z., 325, 1-11.

HOUBAK M.B., ERTBJERG P., THERKILDSEN M. (2008): In vitro study to evaluate the degradation of bovine muscle proteins post-mortem by proteasome and $\mu$-calpain. Meat Science, 79, 77-85.

HUFF-LONERGAN E., MITSUHASHI T., BEEKMAN D.D., PARRISH F.C.J., OLSON D.G., ROBSON R.M. (1996): Proteolysis of specific muscle structural proteins by mu-calpain at low $\mathrm{pH}$ and temperature is similar to degradation in postmortem bovine muscle. Journal of Animal Science, 74, 993-1008.

IWANOWSKA A., IWAŃSKA E., GRZEŚ B., MIKOŁAJCZAK B., POSPIECH E., ROSOCHACKI S., JUSZCZUK-KUBIAK E., ŁYCZYŃSKI A. (2010): Changes in proteins and tenderness of meat from young bulls of four breeds at three ages over 10 days of cold storage. Animal Science Papers and Reports, 28, 13-25.

JAMES S. J., JAMES C. (2002): Meat refrigeration. Woodhead Publishing Ltd and CRC Press LLC.

JOUKI M., KHAZAEI N. (2011): Effects of Storage Time on Some Characteristics of Packed Camel Meat in Low Temperature. International Journal of Animal and Veterinary Advances, 3, 460-464.

MCKENNA D.R., MIES P.D., BAIRD B.E., PFEIFFER K.D., ELLE-BRACHT J.W., SAVELL J.W. (2005): Biochemical and physical factors affecting discoloration characteristics of 19 bovine muscles. Meat Science, 70, 665-682.

MILLER M.F., CARRY M.F., RAMSEY C.B., CROCKETT K.L., HOOVER L.C. (2001): Consumer thresholds for establishing the value of beef tenderness. Journal of Animal Science, 79, 3062-3068.

OLIETE B., CARBALLO J.A., VARELA A., MORENO T., MONSERRAT L., SANCHEZ L. (2006): Effect of weaning status and storage time under vacuum upon physical characteristics of meat of the Rubia Gallega breed. Meat Science, 73, 102-108.

OUALI A. (1990): Meat tenderisation: possible causes and mechanisms. A review. Journal of Muscle Foods, 1,129-165.

SEYFERT M., MANCINI R.A., HUNT M.C., TANG J., FAUSTMAN C., GARCIA M. (2006): Color stability, reducing activity, and cytochrome C oxidase activity of five bovine muscles. J. Agric. Food Chem., 54, 8919-8925. 
TAKAHASHI K. (1996): Structural weakening of skeletal muscle tissue during postmortem ageing of meat: the non-enzymatic mechanism of meat tenderisation. Meat Science, 43, 67-80.

TAPP III W.N., YANCEY J.W.S., APPLE J.K. (2011): How is the instrumental color of meat measured? Meat Science, 89, 1-5.

VIEIRA C., GARCÍA-CACHÁN M.D., RECIO M.D., DOMÍNGUEZ M., SAÑUDO C. (2006): Effect of ageing time on beef quality of rustic type and rustic $\mathrm{x}$ Charolais crossbreed cattle slaughtered at the same finishing grade. Spanish Journal of Agricultural Research, 4, 225-234.

YOUNG O.A., PRIOLO A., SIMMONS N.J., WEST J. (1999): Effects of rigor attainment temperature on meat blooming and colour on display. Meat Science, 52, 47-56.

Received 3 February 2012; accepted for publication 7 February 2012 